\title{
EFEKTIFITAS PEMBELAJARAN BERBASIS DARING: SEBUAH BUKTI PADA PEMBELAJARAN BAHASA INGGRIS
}

\author{
Nurul Lailatul Khusniyah' ${ }^{1}$ \& Lukam Hakim² \\ 12Universitas Islam Negeri Mataram \\ 1․ㅡurullaila@uinmataram.ac.id \& 2lukmanhakim@uinmataram.ac.id
}

\begin{abstract}
Abstrak
Penelitian ini menggambarkan efektifitas pembelajaran berbasis daring terhadap kemampuan mahasiswa dalam memahami teks berbahasa Inggris. Pembelajaran daring yang digunakan dalam penelitian ini adalah pembelajaran yang memanfaatkan penggunaan web blog. Paparan pada artikel ini adalah bagian dari laporan penelitian tindakan kelas yang fokus utamanya adalah melihat efektivitas pembelajaran berbasis daring yang ditinjau dari dua pendekatan, yaitu perbandingan distribusi data dan uji-t pada data sebelum tindakan (pretest) dan setalah tindakan (posttest). Hasil penelitian menunjukkan bahwa ada perbedaan kemampuan pemahaman mahasiswa terhadap teks berbahasa Inggris antara sebelum dan sesudah penggunaan web blog. Dalam hal ini, pembelajaran daring berbantuan web blog tersebut memberikan pengaruh positif terhadap peningkatan kemampuan membaca bahasa Inggris mahasiswa.
\end{abstract}

Kata kunci: Bahasa Inggris, Blog, Membaca

\begin{abstract}
This study describes the effectiveness of online-based learning on the students' ability to understand English-language texts. The online learning used in this study is learning that utilizes the use of web blogs. This article is a part of the report of a classroom action research which focuses on identifying the effectiveness of the online-based learning viewed from two approaches, namely the comparison of data distribution and t-test on the data before the treatments (pretest) and after the treatments (posttest). The results of the study show that there are differences in students' ability to understand English texts before and after the use of the web blogs. In this case, online learning assisted by the web blog has a positive influence on improving students' English reading skills.
\end{abstract}

Keywords: English, Blog, Reading 


\section{PENDAHULUAN}

Perkembangan teknologi informasi dan komunikasi di era Industri 4.0 telah memiliki pengaruh yang besar terhadap proses pengajaran dan pembelajaran. Kemudahan akses teknologi telah digunakan oleh para pengajar untuk meningkatkan kualitas pendidikan. Seperti yang telah disampaikan oleh Keengwe \& Georgina dalam penelitiannya telah menyatakan bahwa perkembangan teknologi memberikan perubahan terhadap pelaksanaan pengajaran dan pembelajaran (Keengwe \& Georgina, 2012). Teknologi informasi dapat diterima sebagai media dalam melakukan proses pendidikan, termasuk membantu proses belajar mengajar, yang juga melibatkan pencarian referensi dan sumber informasi (Wekke \& Hamid, 2013).

Pada era industri 4.0, teknologi digital dapat memberikan dampak buruk bagi dunia pendidikan jika penggunaannya tidak tepat guna. Oleh karena itu, memahami prinsip dan faktor yang mempengaruhi efektivitas teknologi digital dalam pembelajaran adalah sesuatu yang sangat penting bagi seorang pendidik (Putrawangsa \& Hasanah, 2018). Lebih lanjut, Harto (2018) menegaskan bahwa seorang pendidik dituntut untuk memiliki empat kompetensi agar dapat menggunakan teknologi digitial dengan tepat guna. Pertama, seorang pendidik harus memahami dan mampu menggunakan teknologi digital serta penerapannya. Kedua, memiliki kompetensi kepemimpinan yang mampu mengarahkan peserta didik memiliki pemahaman tentang teknologi. Ketiga, mempunyai kemampuan memprediksi dengan tepat arah gejolak perubahan dan langkah strategis menghadapinya. Keempat, mempunyai kompetensi dalam mengendalikan diri dari segala gejolak perubahan, dan mampu meenghadapinya dengan memunculkan ide, inovasi, serta kreativitas.

Sejalan dengan perkembangan kemajuan teknologi, banyak para pengajar bahasa telah memanfaatkan teknologi untuk meningkatkan pengajaran bahasa baik pada Lembaga pendidikan formal atau pesantren 
mulai dari sekolah menengah sampai perguruan tinggi.

Beberapa penelitian telah menunjukkan bahwa teknologi memberikan banyak pengaruh positif terhadap pembelajaran bahasa seperti membaca menggunakan video (Gheytasi, Azizifar, \& Gowhary, 2015). Internet telah dipadukan sebagai alat untuk melengkapi aktivitas pembelajaran bahasa (Martins, 2015). Salah satu media teknologi yang sering digunakan saat ini adalah aplikasi di telepon genggam. Hasil penelitian menunjukan bahwa siswa yang banyak berinteraksi dengan aplikasi di telepon genggam dapat lebih muah memahami isi teks bacaan (Gheytasi et al., 2015). Studi lain menguji tenang strategi membaca siswa di sebagian besar Universitas di Swedia. Data diambil dari aktivitas blog bacaan mahasiswa (McGrath, Berggren, \& Mežek, 2016).

Dari hasil penelitian-penelitian tersebut, peneliti berupaya melakukan inovasi media belajar untuk pembelajaran membaca bahasa Inggris di Program Studi Pendidikan Bahasa Inggris di UIN Mataram. Hasil analisis dokumen hasil belajar dan observasi hasil belajar selama 2 semester disimppulkan bahwa ada masalah hasil belajar. Sebaran angka kelulusan mata kuliah membaca masih rendah di bawah 50\% dan sebagian besar mahasiswa lulus pada rentang nilai 60-70. Padahal jika didorong kembali, kemampuan membaca mahasiswa dapat lebih dari nilai tersebut. Beberapa temuan masalah yaitu mahasiswa masih mengalami kesulitan dalam memahami isi teks bacaan, mahasiswa memiliki kelemahan dalam mengaitkan informasi yang dimiliki dengan teks yang dibaca, mahasiswa memiliki kosakata yang sedikit, dan mahasiswa memiliki kesulitan mengembangkan teks yang dibaca menjadi bacaan baru.

Dari hasil wawancara dan diskusi dengan mahasiswa dan dosen pengajar mata kuliah membaca selama ini proses pembelajaran jarang memanfaatkan teknologi yang telah dimiliki baik oleh kampus ataupun mahasiswa. Padahal media belajar merupakan bagian yang penting dalam menyukseskan pembelajaran di kelas. Oleh karena itu, penelitian ini telah menyajikan blog 
untuk melengkapi proses pembelajaran membaca. Hal ini disebabkan karena hampit semua mahasiswa memiliki fasilitas laptop dan telepon genggam untuk mengakses blog yang telah disediakan oleh pengajar. Blog menyajikan informasi bacaan yang beragam yang bisa dilengkapi dengan video, sehingga proses membaca menjadi menyenangkan. Apalagi sebagian besar waktu mahasiswa juga digunakan untuk bermain telepon genggam. Sehingga melalui pola membaca teks online dalam blog dapat memberikan kemudahan mahasiswa dalam memahami bacaan. Hal ini juga bertujuan agar mahasiswa terbiasa mengakses berbagai macam pengetahuan melalui internet. Di era digital berbagai sumber belajar mulai dari buku sampai media belajar dapat diakses menggunakan fasilitas internet dengan mudah.

Dengan demikian, tujuan dari penelitian ini adalah untuk mengetahui tingkat efektifitas blog terhadap tingkat dan pola membaca bahasa Inggris mahasiswa. Sehingga hasil penelitian ini juga dapat diketahui hasil peningkatan kemampuan membaca mahasiswa dari tes yang diberikan. Adapun rumusan masalah penelitian ini adalah bagaimana peningkatan kemampuan membaca bahasa Inggris mahasiswa melalui pembelajaran menggunakan blog.

\section{LANDASAN TEORI}

\section{Membaca Bahasa Inggris}

Membaca secara umum melibatkan dua keterampilan yaitu dekoding dan pemahaman. Dekoding adalah kemampuan isolable, yang dapat diajarkan dan dinilai dengan cara lugas. Sedangkan pemahaman adalah keterampilan kompleks yang bergantung pada variasi faktor, konteks, dan tujuan membaca. Baik faktor pebelajar, faktor teks, sama seperti halnya pengajaran, semuanya memiliki peranan. Menurut Brassell dan Rasinski, membaca merujuk pada kemampuan untuk memahami atau menciptakan makna dari teks tertulis. Dalam kamus bahwa kata membaca merupakan kemampuan untuk menguji dan memahami makna 
kata dalam teks (Paris \& Stahl, 2005). Jadi, membaca adalah proses seseorang dalam memahami suatu makna dalam teks sesuai dengan tingkat kemampuan yang dimiliki.

Selanjutnya, Kingston dalam Israel menyatakan bahwa "reading is a process of communication by which a message is transmitted graphically between individuals (Israel, et.al, 2005). Jadi, membaca merupakan proses komunikasi dimana pesan disampaikan secara grafis kepada individu. Membaca merupakan proses interaktif atau timbal balik antara pembaca dan sumber informasi. Pembaca memahami makna yang ada dalam teks berdasarkan pada interpretasi mereka.

Pendapat berbeda diungkapkan oleh Scanlon, Anderson, \& Sweeney (2010) bahwa membaca adalah proses kompleks yang mensyaratkan adanya analisis, koordinasi, dan interpretasi terhadap berbagai macam sumber informasi. Dengan demikian, secara efektif menimbulkan kebutuhan literasi pebelajar, khususnya bagi yang mau berjuang, kebutuhan pembelajaran untuk mengambil sejumlah kegiatan kompleks. Jadi, membaca adalah proses bagi seseorang dalam menganalisis dan menginterpretasikan makna yang tercantum dalam sumber informasi atau teks.

Selain itu, kegiatan membaca menimbulkan kebutuhan literasi dari seseorang agar mampu menciptakan makna yang ingin diperoleh. Johnson (2008) menyatakan bahwa membaca memiliki beberapa definisi antara lain, a) membaca adalah praktik menggunakan teks untuk menciptakan makna; b) membaca adalah proses pengembangan keterampilan; c) membaca adalah integrasi visual dan informasi nonvisual; dan d) membaca adalah tindakan yang berhubungan dengan ide lain.

Baker mengungkapkan bahwa membaca dan mendengarkan merupaka proses yang saling membutuhkan tidak hanya untuk memahami makna literal atau harfiah, tetapi memahami gagasan- 
gagasannya. Hal ini selaras dengan Tierney yang menyatakan bahwa pembelajaran untuk membaca tidak hanya belajar untuk mengenali kata; juga pembelajaran untuk mebuat makna teks lebih logis. Karena membaca merupakan interaksi empat hal yaitu pembaca, teks, kelancaran membaca dan strategi membaca. Pendapat tersebut telah tertuang dalam penelitian Nejad dan Mahmoodi-shahrebabaki untuk meningkatkan efektifitas pengajaran dan pembelajaran membaca pemahaman dan strategi membaca menggunakan pendekatan CALLA menunjukkan adanya hubungan positif yang signifikan antara penggunaan CALLA dan kemampuan memahami bacaan (Nejad \& Mahmoodi-Shahrebabaki, 2017).

Dengan demikian, dapat dipahami bahwa membaca merupakan proses seseorang dalam memahami makna suatu teks. Dalam proses membaca membutuhkan kombinasi aktivitas kompleks seperti pemahaman arti kosa kata, fonemik, dan kalimat. Membaca membutuhkan dukungan informasi baik secara visual maupun tidak. Jadi, mahasiswa dalam penelitian tindakan ini belajar membaca dengan baik agar mengerti makna teks. Dengan demikian, mahasiswa dapat memanfaatkan kemampuan membaca untuk kehidupan sehari-hari baik untuk kepentingan proses pendidikan, pekerjaan, dan kehidupan sosial.

\section{Web blog sebagai media pembelajaran daring}

Blog merupakan log web yang dirancang untuk mempublikasikan suatu informasi oleh seorang penulis. Bagi beberapa orang blog digunakan untuk kepentingan proses pembelajaran, karena kemudahan dalam mengakses informasi tanpa memiliki akun. Menurut Torres, blog telah menjadi sarana menyenangkan bagi beberapa orang untuk menyelesaikan pekerjaan dan keperluan akademik, seperti di sekolah para guru telah menggunakan blog untuk media belajar (Azizinezhad \& Hashemi, 2011). Blog telah mendorong siswa untuk mengembangkan pengetahuan dan keterampilan baru yang diperlukan untuk profesi 
mereka. Dari laporan evaluasi pelajaran dan kuesioner, tampaknya para siswa telah memiliki pengalaman yang memuaskan. Mereka merasa bahwa mereka telah lebih siap untuk mendukung pekerjaan atau profesi dengan membaca dan belajar dari ide orang lain tentang pengajaran bahasa, dan menerapkan teknologi baru (Okan \& Taraf, 2013).

Dalam penelitian Özdemir \& Aydın (2015) blog sebagai media online dapat digunakan untuk proses pembelajaran melalui pendekatan berbasis proses. Sehingga para siswa dapat meningkatkan kemampuan mereka baik meliputi konten, organisasi, penanda wacana, kosakata, konstruksi kalimat dan mekanisme penulisan. Namun, perlu dipahami bahwa penggunaan blog tidak memiliki pengaruh positif terhadap konstruksi kalimat. Smith mengakui bahwa beberapa tahun terakhir telah menjadi tren sekolah-sekolah menggunakan blog untuk mempromosikan sekolah. Sekolah berpikir dengan cara seperti dapat menarik minat siswa untuk menggunakan teknologi. Pernyataan ini juga diperkuat oleh Yanuar yang menyatakan bahwa blog dapat diakses secara bebas selama pengguna memiliki computer dan koneksi internet. Artinya bahwa teknologi dapat dijangkau oleh siapapun (Rahman Sidek \& Md.Yunus, 2012).

Dalam penelitian ini, blog dimanfaatkan sebagai media belajar untuk proses pembelajaran membaca bahasa Inggris. Hal ini bertujuan agar mahasiswa dapat membaca dimanapun di luar kelas. Blog dirancang dosen agar semua mahasiswa dapat langsung mengakses bacaan yang disajikan di blog. Selanjutnya, mereka dapat dengan mudah menganalisis isi teks bacaan. Dengan demikian, dosen juga dapat mempublikasikan kembali hasil analisis mahasiswa terhadap teks yang sudah dibaca untuk mendapatkan penilaian dari mahasiswa lain.

\section{METODE}

Penelitian ini adalah bagian dari serangkaian penelitian tindakan kelas (tiga siklus) yang fokus utamanya adalah mengidentifikasi efektivitas 
penggunaan web blog dalam pembelajaran Bahasa Inggris untuk meningkatkan kemampuan mahasiswa dalam memahami teks berbahasa Inggris.

Sumber data penelitian adalah mahasiswa semester III tahun ajaran 2018/2019 sebanyak 68 orang yang tersebar pada 2 kelas di Program Studi Bahasa Inggris UIN Mataram. Data dikumpulkan dengan metode tes. Tes dikembangkan untuk menguji kemampuan mahasiswa dalam memahami informasi yang disajikan dalam teks berbahasa Inggris. Tes diberikan dua kali, yaitu pretes dan postes, untuk mengidentifikasi perubahan kemampuan mahasiswa dalam memahami teks berbahasa Inggris sebelum dan sesudah perlakuan diberikan.

Efektivitas pembelajaran berbasis daring (yaitu pembelajaran berbantuan web blog) ditinjau dari dua pendekatan, yaitu: Pertama, membandingkan distribusi data sebelum tindakan (pretest) dan setalah tindakan diberikan (posttest). Distribusi data dalam hal ini meliputi nilai ratarata, median, modus, interval data, variansi data, dan standar deviasi data. Selain itu, perbandingan distribusi data juga dilakukan pada hasil tes pada setiap siklus untuk melihat perubahan kemampuan mahasiswa sebagai dampak dari penerapan pembelajaran berbasis daring.

Kedua, menggunakan uji t untuk menguji asumsi/hipotesis yang dibangun dalam penelitian. Adapaun hipotesis dalam penelitian ini dinyatakan dalam pernyataan berikut ini: ada perbedaan kemampuan siswa dalam memahami teks berbahasa Inggris antara sebelum dan sesudah penggunaan pembelajaran berbasis web blog. Hipotesis nol dalam penelitian ini adalah inversi dari hipotesis dalam penelitian ini seperti yang telah dinyatakan sebelumnya.

Selain itu, dalam penelitian ini, penilaian sejawat digunakan untuk konfirmasi hasil analisis penelitian, guna menjaga nilai objektifitas temuan dalam penelitian ini. 


\section{HASIL DAN PEMBAHASAN}

Uraian pada bagian ini dibagi dalam dua bagian, yaitu begian pertama mengungkap temuan penelitian berdasarkan perbandingan distribusi data dan uji-t. Sedangkan bagian kedua difokuskan pada diskusi tentang hubungan hasil penelitian ini dengan teori atau penelitian terdahulu yang terkait.

\section{Kemampuan membaca bahasa Inggris mahasiswa}

Berdasarkan pada hasil analisis data dengan kolaborator, table 1 menunjukkan perbandingan hasil perhitungan statistik deskriptif dari tes mahasiswa yang telah diberikan sebelum dan sesudah menggunakan blog. Terdapat perbedaan nilai rata-rata tes membaca bahasa Inggris. Ada perubahan yang signifikan dari pre-test ke post-test. Ada peningkatan 23,7 point. Nilai rata-rata telah memenuhi kriteria keberhasilan tindakan. Begitupun pada hasil nilai tertinggi mencapai 90. Pada saat sebelum penerapan blog, nilai terendah mencapai 32 dan tertinggi 75. Sedangkan sesudah proses pembelajaran menggunakan blog diketahui bahwa nilai terendah sebesar 70 dan nilai tertinggi Artinya bahwa tingkat keberhasilan dari blog telah memberikan pengaruh yang besar terhadap peningkatan kemampuan membaca bahasa Inggris. Selain itu, perbedaan besar juga terlihat dari nilai harian setiap mahasiswa, seperti terlihat pada grafik di bawah ini;

\section{Tabel 1.}

Perbandingan Hasil Tes Membaca Bahasa Inggris Sebelum dan Sesudah Menggunakan Web Blog

\begin{tabular}{llll}
\hline No & Distribusi & Sebelum & Sesudah \\
\hline 1 & Nilai rata-rata & 57,5 & 81,2 \\
2 & Median & 55 & 80 \\
3 & Modus & 55 & 80 \\
4 & Nilai terendah & 32 & 70 \\
5 & Nilai tertinggi & 75 & 90 \\
6 & Varian & 87,7 & 21 \\
7 & Standar deviasi & 9,4 & 4,6 \\
\hline
\end{tabular}




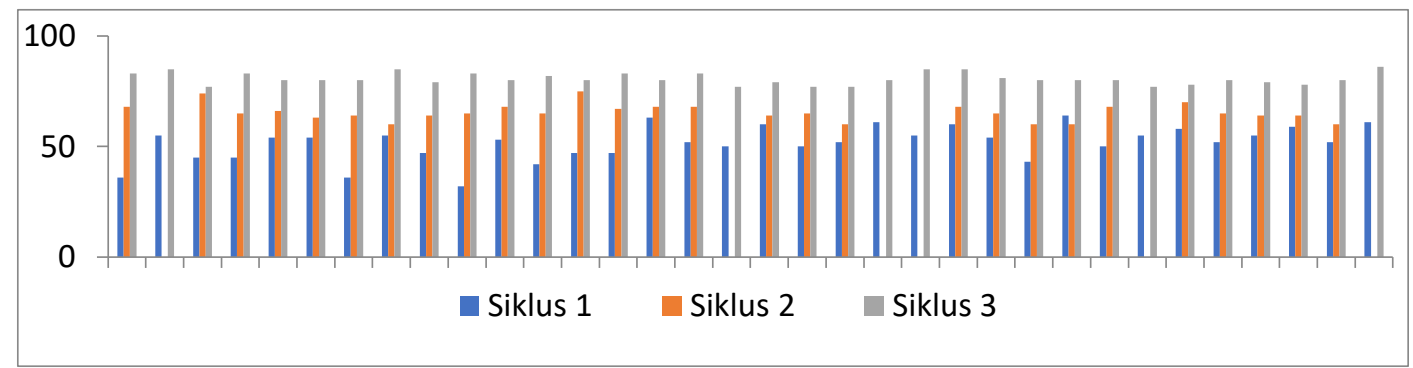

Grafik 2. Perbandingan hasil tes pada siklus pertama, kedua dan ketiga



Grafik 3. Perkembangan kenaikan rata-rata nilai tes pada ketiga siklus

Dari grafik 2 menunjukkan peningkatan nilai tes yang diperoleh mahasiswa dari siklus pertama sampai siklus ketiga. Setiap orang mengalami peningkatan nilai yang konsisten. Dari hasil nilai rata-rata yang diperoleh juga telah menunjukkan perbedaan yang cukup signifikan. Pada siklus pertama diperoleh nilai terendah 0 karena masih ada mahasiswa yang tidak hadir dan nilai tertinggi sebesar 65, serta nilai rata-rata 51,5. Siklus kedua menunjukkan nilai terendah sebesar 0 , nilai tertinggi 75 , dan nilai rata-rata sebesar 62. Sedangkan siklus ketiga menunjukkan nilai terendah sebesar 77, nilai tertinggi sebesar 90, dan nilai rata-rata 82,3. Berikut ini grafik kenaikan nilai rata-rata nilai harian dari siklus pertama ke siklus ketiga;

Sedangkan hasil uji independent t-test untuk mengetahui perbedaan kemampuan membaca bahasa Inggris mahasiswa sebelum dan sesudah perlakuan ditunjukkan oleh tabel 2 .

Tabel 2.

Hasil uji-t terhadap data pretes dan postes 


\begin{tabular}{lrr}
\hline & Pre-test & Post-test \\
\hline Mean & 57.57 & 81.176 \\
Variance & 87.681 & 22.475 \\
Observations & 68 & 68 \\
Pearson Correlation & 0.19 & \\
Hypothesized Mean Difference & 0 & \\
Df & 67 & \\
t Stat & -20.16 & \\
P(T<=t) two-tail & 3.71 & \\
t Critical two-tail & 1.99 & \\
\hline
\end{tabular}

Tabel 2 menunjukkan perbedaan nilai yang cukup signifikan untuk tingkat kemampuan membaca bahasa Inggris mahasiswa sebelum dan sesudah menggunakan blog. Hasil olahan data disimpulkan bahwa $t$-Stat (-20.16) < t-table (1.85), artinya bahwa Ho ditolak dan H1 diterima. Disamping itu, jika dilihat hasil dari $P(T-t)$ two-tail detemukan bahwa (3.71) $>$ t-table $(t$ Critical two-tail $)=1.99$. Dengan demikian dapat dikatakan bahwa terdapat perbedaan kemampuan siswa dalam memahami teks berbahasa Inggris antara sebelum dan sesudah penggunaan pembelajaran berbasis web blog.

\section{Pembahasan}

Dari hasil analisis data diketahui bahwa blog cukup efektif untuk melengkapi implementasi dari pendekatan pembelajaran di kelas membaca. Tahapan implementasi dari blog di kelas membaca bahasa Inggris telah disesuaikan dengan pendekatan pembelajaran yang digunakan selama ini, yaitu pendekatan kontekstual. Karena dalam memahami suatu bacaan mahasiswa harus mengetahui konteks dari setiap teks, agar materi yang ingin disampaikan oleh penulis dapat diterima oleh pembaca. Langkah pertama, dosen membuat blog khusus untuk proses pembelajaran membaca yang disesuaikan dengan kebutuhan dan tujuan mata kuliah ini. Sebelum kelas dimulai, dosen memasukkan berbagai macam teks dan referensi buku serta video yang memiliki skrip agar mahasiswa mudah membaca. Pada blog tersebut, 
dosen juga menyediakan kolom komentar. Selanjutnya kegiatan pembelajaran di kelas disesuaikan dengan implementasi pendekatan kontekstual melalui blog. Dosen membuka blog untuk menginformasikan kepada mahasiswa agar mereka membaca teks tersebut, setelah itu mahasiswa diminta untuk menganalisis sesuai dengan pengalaman konteks pengetahuan mereka. Dosen memeriksa hasil analisis teks tersebut dan mempublikasikannya di blog kembali agar mendapatkan masukan dari mahasiswa lain. Mahasiswa memiliki kewajiban membaca sampai dengan 700 halaman untuk dua belas pertemuan. Jadi, mahasiswa dapat membaca ringkasan teks-teks yang dipublikasikan di blog oleh dosen.

Kegiatan pembelajaran tersebut cukup efektif, karena berbagai macam referensi yang digunakan telah ada di blog. Mahasiswa di luar kelas dapat membaca tanpa harus mencari referensi-referensi tersebut. Selain itu, mahasiswa juga memiliki rasa nyaman berbeda dalam belajar dengan adanya kemudahan mengakses informasi. Seperti dalam penelitian yang telah dilakukan oleh Cakir (2013) bahwa mahasiswa memiliki alasan yang tepat untuk termotivasi dan nyaman belajar dalam menggunakan blog.

Dari review studi yang telah dilakukan peneliti lain tentang penggunaan blog dalam pembelajaran EFL, beberapa kesimpulan dapat ditarik. Pertama, blogging sebagai strategi pembelajaran bahasa memberikan kontribusi yang signifikan untuk meningkatkan pengetahuan budaya pelajar dan kesadaran budaya tentang masyarakat sasaran. Selain itu, penggunaan blog meningkatkan interaksi budaya, kompetensi, dan pertukaran pelajar. Kedua, blogging memainkan peran penting dalam mengembangkan interaksi dan komunikasi peserta didik dalam bahasa target. Ketiga, blog adalah alat yang efektif untuk mengembangkan keterampilan berbicara, membaca, dan menulis. Namun, berkenaan dengan keterampilan berbicara, sementara blog efektif untuk 
mengembangkan keterampilan yang berkaitan dengan konseptualisasi, curah pendapat, artikulasi, pemantauan, evaluasi, penyajian diri dan pertukaran informasi, mereka tidak berpengaruh pada kelancaran, keakuratan, kompleksitas bahasa, atau pengucapan. Selain itu, penelitian menunjukkan bahwa penggunaan blog meningkatkan proses membaca, menghasilkan persepsi positif membaca, mendorong diskusi kelas, dan mengembangkan keterampilan membaca dan berpikir kritis (Cakir, 2013).

Dari paparan penelitian sebelumnya dan temuan data diketahui bahwa blog memberikan kebiasaan membaca yang menyenangkan. Namun peneliti telah menemukan bahwa blog tidak memberikan pengaruh terhadap hasil tes. Akan tetapi peningkatan kemampuan membaca bahasa Inggris mahasiswa dari hasil pembiasaan mahasiswa membaca dengan rasa nyaman dan suatu kebutuhan untuk mendapatkan informasi dan pengetahuan. Rasa seperti ini sangat penting dan berdampak pada peningkatan motivasi untuk belajar. Karena jika seseorang sudah merasa nyaman dengan media belajar dan lingkungan belajar, secara langsung terbangun kebiasaan belajar seperti membaca menjadi kebutuhan.

\section{KESIMPULAN}

Hasil analisis data menunjukkan ada pengaruh positif dari blog terhadap proses pembelajaran membaca bahasa Inggris. Sehingga berdampak pula terhadap peningkatan nilai yang diperoleh oleh mahasiswa. Selain itu, perkembangan nilai harian mahasiswa juga telah menunjukkan peningkatan yang cukup signifikan. Oleh karena itu, hasil penelitian ini memiliki implikasi terhadap kualitas pengajaran dan pembelajaran membaca di kelas. Para dosen bisa menggunakan blog sebagai media pelengkap agar proses pembelajaran lebih menyenangkan. Blog tidak hanya bisa digunakan untuk mata kuliah membaca, tetapi bisa juga digunakan untuk mata kuliah lain yang 
sesuai dengan rancangan pembelajaran. Untuk menjadikan proses belajar menjadi lebih inovatif, dosen bisa merancang blog dengan layout yang memiliki karakteristik mata kuliah.

\section{PENGAKUAN}

Ucapan terima kasih disampaikan kepada mahasiswa semester III tahun ajaran 2018/2019 yang telah membantu terlaksananya penelitian ini. Ucapan terima kasih juga disampaikan kepada semua pihak yang telah membantu penelitian ini.

\section{DAFTAR PUSTAKA}

Azizinezhad, M., \& Hashemi, M. (2011). The Use of Blogs in Teaching and Learning Translation. Procedia - Social and Behavioral Sciences, 28, 867871. https://doi.org/10.1016/J.SBSPR0.2011.11.159

Cakir, H. (2013). Use of blogs in pre-service teacher education to improve student engagement. Computers \& Education, 68, 244-252. https://doi.org/10.1016/J.COMPEDU.2013.05.013

Creswell, J. W. (2012). Educational Research: Planning, Conducting, and Evaluating Quantitative and Qualitative Research. London \& New York: Pearson Education.

Gheytasi, M., Azizifar, A., \& Gowhary, H. (2015). The Effect of Smartphone on the Reading Comprehension Proficiency of Iranian EFL Learners. Procedia - Social and Behavioral Sciences, 199, 225-230. https://doi.org/10.1016/J.SBSPR0.2015.07.510

Harto, K. (2018). TANTANGAN DOSEN PTKI DI ERA INDUSTRI 4.0. Jurnal Tatsqif, 16(1), 1-15. Retrieved from http://journal.uinmataram.ac.id/index.php/tatsqif/article/view/159

Israel, S. E. (n.d.). Metacognition in Literacy Learning Theory, Assessment, Instruction and Professional Development. Mahwah: Lawrence Erlbaum Associates, Inc.

Johnson, A. P. (2008). Teaching Reading and Writing a Guidebook for Tutoring and Remediating Students. (R. dan L. Education, Ed.). New York.

Keengwe, J., \& Georgina, D. (2012). The digital course training workshop for online learning and teaching. Education and Information Technologies, 17(4), 365-379. https://doi.org/10.1007/s10639-011-9164-X

Khabiri, M., \& Pakzad, M. (2012). The Effect of Teaching Critical Reading 
Strategies on EFL Learners' Vocabulary Retention. Journal of Teaching Language Skills, 31(1), 73-106. https://doi.org/10.22099/JTLS.2012.325

Martins, M. de L. (2015). How to Effectively Integrate Technology in the Foreign Language Classroom for Learning and Collaboration. Procedia Social and Behavioral Sciences, 174, 77-84. https://doi.org/10.1016/J.SBSPR0.2015.01.629

McGrath, L., Berggren, J., \& Mežek, Š. (2016). Reading EAP: Investigating high proficiency L2 university students' strategy use through reading blogs. Journal of English for Academic Purposes, 22, 152-164. https://doi.org/10.1016/J.JEAP.2016.03.003

Nejad, B., \& Mahmoodi-Shahrebabaki, M. (2017, October 24). Effects of Metacognitive Strategy Instruction on the Reading Comprehension of English Language Learners Through Cognitive Academic Language Learning Approach (Calla). Retrieved from https://papers.ssrn.com/sol3/papers.cfm?abstract_id=3058349

Okan, Z., \& Taraf, H. U. (2013). The Use of Blogs in Second Language Teacher Education. Procedia - Social and Behavioral Sciences, 83, 282-289. https://doi.org/10.1016/J.SBSPRO.2013.06.055

Özdemir, E., \& Aydın, S. (2015). The Effects of Blogging on EFL Writing Achievement. Procedia - Social and Behavioral Sciences, 199, 372-380. https://doi.org/10.1016/J.SBSPR0.2015.07.521

Paris, S. G., \& Stahl, S. A. (2005). Children's Reading Comprehension and Assessment. New Jersey: Lawrence Erlbaum Associates, Inc.

Putrawangsa, S., \& Hasanah, U. (2018). INTEGRASI TEKNOLOGI DIGITAL DALAM PEMBELAJARAN DI ERA INDUSTRI 4.0. Jurnal Tatsqif, 16(1), 4254. Retrieved from

http://journal.uinmataram.ac.id/index.php/tatsqif/article/view/203

Rahman Sidek, E. A., \& Md.Yunus, M. (2012). Students' Experiences on using Blog as Learning Journals. Procedia - Social and Behavioral Sciences, 67, 135-143. https://doi.org/10.1016/J.SBSPR0.2012.11.314

Scanlon, D. M., Anderson, K. L., \& Sweeney, J. M. (2010). Early Intervention for Reading Difficulties. New York: The Guilford Press.

Wekke, I. S., \& Hamid, S. (2013). Technology on Language Teaching and Learning: A Research on Indonesian Pesantren. Procedia - Social and Behavioral Sciences, 83, 585-589. https://doi.org/10.1016/J.SBSPR0.2013.06.111 